\title{
Practice and application of multi-dimensional interactive teaching model in College English Teaching
}

\author{
Yang Hua \\ Shaanxi Xueqian Normal University,Shaanxi Xi'an,710100
}

Keywords: Colleges and universities, English, Teaching, Multidimensional interaction, Teaching mode.

\begin{abstract}
This paper mainly introduces the reform direction of the current college English teaching, and further analyzes the connotation of interactive teaching mode number, at the end of the article, the author introduces the application strategy of the current existing problems in College English teaching and the multi-dimensional interactive teaching model in College English teaching.
\end{abstract}

\section{Introduction}

With the continuous development of the socialist market economy in China, in order to better meet this demand, the education sector has begun to actively cooperate with major universities to provide more English teaching help for them. In the whole process of the change of College English teaching model, to more fully and deeply implement the principle of combining theory with practice, through strengthening the application of students in English, to further improve the English ability of students. Through effective external stimulation and strengthening students' psychological cognitive process, the purpose of English teaching is further improved. In China's coastal cities, international exchanges are becoming more and more common, and the demand for advanced application talents is also increasing. English application comprehensive ability is one of the basic abilities that undergraduates must master. It is necessary for universities to develop multi-dimensional interactive teaching mode. By teaching students to listen, speak, read and write, and further standardize the mode of running schools, English teaching will be pushed to a peak. Multidimensional interaction pattern effectively breaks the traditional English teaching mode and examination oriented education, to be specific to the individual, pay attention to cultivating students' ability, can no longer be Tangguan teaching. The traditional curing thinking has seriously affected the quality of English talents. If we do not make innovations in such circumstances, the result can only be gradual retrogression. Using cooperative teaching method to realize multi-dimensional interactive teaching is the optimization strategy of College English teaching reform. The traditional teaching model pays attention to training students' knowledge and skills, but pays little attention to students' practical ability and cognition, and pays more attention to students' inner spiritual needs. Under normal circumstances, such teaching methods tend to make students suffer emotional inhibition, many characteristics can not be fully developed. In the new era, people need to update the educational model, starting from both material and spiritual aspects, in line with the rapid development of society. In essence, education is not only to enable students to change their fate through knowledge, but also to educate students to be full of passion and vitality, and achieve a good life value. "Student oriented" teaching concept is the product of the times[1].

\section{The connotation of multidimensional interactive teaching model}

Modern teaching emphasizes that students should not only learn to cognize, but also master the methods of communication and communication in the process of receiving education. The multidimensional interactive teaching model has much in common with the content advocated by modern teaching. The essence of multidimensional teaching theory is to take students as the center, and construct a good teaching theme through the interaction between students and students. 
Multidimensional interactive teaching model advocates students as the main body, encourages students to communicate, cooperate and explore in the classroom, and really make students master the classroom, so that students can feel the joy of learning[2].

The theory of multidimensional interactive teaching model is concerned with the theory of constructivism. In the process of teaching, teachers play the roles of a guider and an assistant, and students are a construction subject in the process. Such teaching methods emphasize the students' dominant position and enhance their desire to learn. The teacher is responsible for serving the students' understanding and the work of the classroom process organization. Not only that, but the condition of learning English lies in internalization. Only by defining the input content of language can we further clarify what kind of output we can use. The output is the result of the internalization of the students. As a language, English has strong practice. Traditional English teaching pays more attention to instilling more knowledge for students, but neglects to cultivate students' language skills. The emphasis and difficulty of College English teaching should be to train students' practical ability. Under this background, the implementation of multi-dimensional interactive teaching mode of College English, can better promote the virtuous cycle between teachers and students, further improve the quality of teaching, strengthen students' ability of english.

In the construction of a specific interactive teaching model, multimedia teaching, autonomous learning, and the simultaneous application of english. The multimedia teaching is a teacher centered teaching mode, according to the curriculum requirements and methods of English teaching, the multimedia design, let students into the concrete teaching situation, increase students' interest in learning. Through group cooperation, the practice of many people, the good interaction between students and students, and the effective communication between teachers and students, at the same time, students into the process of learning, but also the process of optimizing the teaching of teachers. To strengthen students' ability of using English, dictation and reading back to carry out some activities to enhance the students practice English ability, promote students to better construct their own knowledge structure, team consciousness and consciousness, cultivate students' cultural awareness, in general, the English Teaching in Colleges and universities, not only confined to instill knowledge, more it is important to develop the ability of[3].

\section{The problems existing in College English Teaching}

At present, College English teaching is still only pay attention to student achievement, and as a measure of students' English learning ability of quality standards, whether it is for down if things go on like this, the students' ability of cognitive or emotional aspects will be affected, and the innovation of teaching reform usually only emphasizes form and teaching content, ignoring the students' psychological and emotional considerations, which will further affect the teaching effect. In the actual teaching, we pay too much attention to the status of teachers, and students can only passively accept knowledge, which will further lead to two levels of differentiation in the classroom.

The classroom atmosphere will influence the students' behavior habit to a certain extent, and it will also exert a decisive influence on the students' learning motivation. Many students think English class is boring and not too flexible, which will affect students' learning enthusiasm to a certain extent. If there is no good interaction between teachers and students, they can not achieve good teaching results. The teacher does not understand the student's idea, cannot help the student to create the good study atmosphere, the student naturally does not want to attend the lecture.

In the teaching process, many teachers to the students' interest and hobbies are poorly understood, but there are some basic communication in the classroom after class, teachers and students do not understand the basic zero communication between teachers and students, which will lead to more and more gap between teachers and students. In addition, influenced by the traditional teaching methods, the English class is always in the state of continuous explanation by the teacher and the students' pleasant talk. In such an atmosphere, English classes will only become increasingly dull and boring.

For Chinese students, English is a foreign language. It is not a process of learning knowledge, 
but also a process of mastering a tool. But students are often afraid of making mistakes in English learning, and they feel ashamed to speak english. In addition, in the process of intercultural communication, there are many differences between Chinese and English culture, students are very strange to these differences, which will lead to the lack of information to learn English, learn English if things go on like this there will be some obstacles[4].

\section{Multidimensional interactive teaching model in College English Teaching Strategies}

Improving students' self-confidence requires teachers to do well in extracurricular teaching. Therefore, from the point of view of teaching, teachers need to pay close attention to students who are more backward in their achievements and give them some encouragement. At the same time, we should not forget to praise outstanding students. From the point of view of extracurricular teaching, teachers need to actively communicate with students and encourage students to use English more in their daily life. Teachers also need to encourage students to take part in activities such as dubbing and English drama performances.

In the multi-dimensional interactive teaching mode, teachers should change their teaching ideas, establish a correct and reasonable teaching thinking, not only on the performance of students learning English is regarded as evaluation standard of the students, only to change ideas, to better in English Teaching in multi-dimensional interactive teaching. In practice, teachers should change the role of teachers and students, abandon their own superior status, adhere to the people-oriented, effectively play the dominant position of students, if students lack enthusiasm for learning, then no matter how indoctrination, cannot have a good teaching effect. Therefore, through the subtle influence of teachers, the initiative and independence of students can be cultivated, and the teaching process will be expanded in a more dimensional manner. In this process, stimulate students' awareness of problems, encourage them to use their knowledge, deal with problems, and learn to innovate constantly.

Abundant teaching activities can help to enhance classroom interaction. In the multi-dimensional interactive teaching mode, teachers should create various teaching activities, and further urge students to have a multi-dimensional interactive experience. The interaction between teachers and students, students and students should spread to each other instead of limiting teaching activities to a single process. In practical teaching, not only teachers and students need more questions and answers, but also students need to discuss and interview. For example, students are free to form a group, debating by different groups of students, or performing task scenario simulations. Teachers give students a certain degree of confidence, so that they dare to participate in learning activities in order to gain more practical interest. In the multi-dimensional interactive teaching mode, teachers should adopt a variety of evaluation methods to encourage students to progress and develop. The entire evaluation process is not limited to the evaluation of teachers, but also to guide students to actively evaluate and appreciate each other. For example, self-evaluation within the group, mutual evaluation between groups, whether a result of reporting or mutual communication, can make students progress.

Teachers should conduct collective classes, through reading, textbook integration, different levels and analyzing their characteristics, determine a targeted teaching goal, and then set the task of teaching, through the recording micro class video, listening materials, making the guiding case and self testing problem etc. and then do the preparation of relevant information. In the past teaching mode, most of them are "one size fits all" teaching, many times, excellent students learn poorly, poor students will not learn, so it will further affect the development of students' personality, ability to develop. In the specific multidimensional classroom, students can adjust their learning direction according to their own degree. Teachers can also understand the students' specific learning situation from the students' pre class learning situation, find the difficulties that students will encounter in their study, further enhance the pertinence of teaching and optimize the teaching effect. Using multidimensional interactive teaching mode, teachers should create various interesting learning situations. In actual teaching, teachers should be closely linked to life, mining can make use of the elements of life, give students more creative whimsy space, to further enhance the 
students' initiative and enthusiasm in learning, enhance students' emotion, and help students better learning and mastering english. To encourage students to encounter problems in the process of self to teachers and classmates for help, to ensure that the problem can be solved in time, at the same time, teachers can also adjust their teaching methods according to the feedback information of the teaching platform.

The purpose of teaching, based on students' overall, improve the students' English learning level uneven problems, through the entrance examination for students, can be divided into A, B, C three grades, different teaching methods to different levels of students. Students with different starting points can use rolling teaching methods, from top to bottom. Create a new student evaluation system, in the process of learning, to strengthen the supervision and management of the students' application ability, treat the students usually do the assessment, to achieve a combination of written and oral examinations, make the learning process and results of each other, students can independently in the usual oral English training, and will be listed within the daily performance appraisal the scope of application of the proportion of intensive english[5].

In the specific teaching process, colleges and universities often attach importance to the results of classroom teaching, but they do not pay attention to students' ability in independent learning. In the multi-dimensional interactive mode, colleges and universities should further strengthen the cultivation of students' independent learning ability, and cultivate students' better practical ability. A lot of teachers should interact with students in teaching, encourage students and students to interact, to enable students to read some extracurricular books, enhance the knowledge of the barricade, so as to meet the needs of multi-dimensional interactive teaching. This is an important means for students to broaden their horizons and enhance students' interest in learning. Through group cooperation and multi person learning, we can complete the practical training of language and achieve the interaction between teachers and students, students and students. English application includes not only the students' reading and writing, which also heard that these parts in autonomous learning, listening and speaking is an emphasis on content, but also the characteristics of autonomous learning, teaching and counseling method by tracking at the same time, enhancing the students' ability to solve the problem of students, dumb English, let the university the students can really learn how to use english[6].

\section{Conclusion}

Multidimensional interaction teaching pattern is the inevitable demand of China's economic and cultural development, but also to enhance the ability of College English teaching requirements, this helps to push up the college students' listening speaking reading and writing ability, the students in the teaching process, to achieve full participation, to achieve autonomous learning, optimize their interaction ability. With the rapid development of economy, international communication is becoming more and more frequent. If we want to get out of the world better, we need to master English. It is not only an interest, but also a kind of ability.

\section{References}

[1]Liu L, Zheng W. Construction of Multi-dimensional Interactive College English Teaching Model[J]. Journal of Anshun University, 2014.

[2]Tang L L, Chen C D. The effect and evaluation index system of multi-dimensional interactive ideological and political theory course teaching mode in higher vocational colleges[J]. Journal of Minxi Vocational \& Technical College, 2013.

[3]Yang C L, Cheng Y P. Study on Multi-dimensional Interactive English Teaching Model[J]. Journal of Tonghua Normal University, 2008.

[4]Peng L, Electronics D O, University H. Research on Multi-Dimensional Interactive Teaching Model of Communication Principle Course[J]. Modern Computer, 2013. 
[5]Wang H. Preliminary Study on Multi-Dimensional Interactive Model in Large Classes Teaching Environment[J]. Journal of Henan Mechanical \& Electrical Engineering College, 2011.

[6]Zhang B, Shuqian L I, Sun X, et al. Study on the modeof multi-dimensional interactive teaching through the course of genetics teaching in biological of universities[J]. Journal of Anshan Normal University, 2016. 